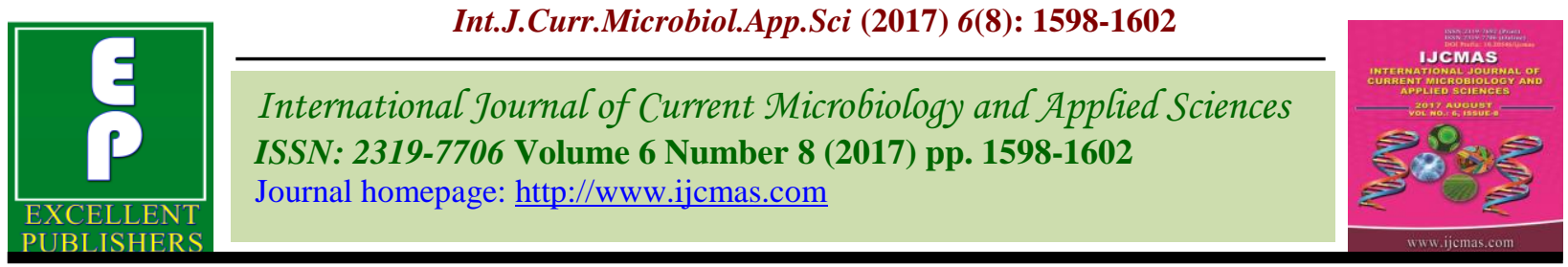

Original Research Article

https://doi.org/10.20546/ijcmas.2017.608.191

\title{
Survey and Surveillance of Target Leaf Spot Disease (Corynespora cassiicola) in Soybean Growing Area of Chhattisgarh, India
}

\author{
Arvind Kumar Kurre*, Meghchand Dewangan and Kamalnarayan Koshle
}

Department of Plant Pathology, Indira Gandhi Krishi Vishwavidyalaya, Raipur - 492001,

Chhattisgarh, India

*Corresponding author

\section{A B S T R A C T}

Target leaf spot disease of soybean caused by Corynespora cassiicola. The

Keywords

Target leaf spot,

Corynespora

cassiicola.

Article Info

Accepted:

17 June 2017

Available Online:

10 August 2017 disease affects leaves, stems, pods and seeds. Leaf lesions are rounded to irregular and reddish brown; they vary from specks to big mature spots. Lesions are frequently surrounded by a dull green or yellowish green halo. In Survey studies an intensive disease survey of the target leaf spot disease of soybean during June to August in Kharif 2015 was undertaken in different soybean growing area at Bemetra, Saja, Mungeli, Kawarda, Lohara, Gandai, Chhuhikhadan, Khairagarh, Rajnandgaon of Chhattisgarh region the minimum disease severity and incidence was observed in Bemetra block. Most of the fields in the surveyed blocks were moderately and trace infected with the disease while few were severely infected. Variety JS 335 was highly susceptible to disease in all the blocks.

\section{Introduction}

Soybean (Glycine max. L. Merril) belonging to family Leguminaceae is designated as miracle bean established its potential as an industrially vital and viable oilseed crop in many areas of India. The target leaf spot disease of soybean causes by (Corynespora cassiicola) was first reported in 1945 (Olive et al., 1945). Now it has been found in most of soybean growing states. In Chhattisgarh it has been reported during 2002 from Raipur (Patel, 2005).The disease affects leaves, stems, pods and seeds. Leaf lesions are rounded to irregular and reddish brown; they vary from specks to big mature spots. Lesions are frequently surrounded by a dull green or yellowish green halo. Severely affected leaves drop prematurely (Sinclair, 1982). The fungus over winters on soybean debris and seed. It can survive in a fallow field for two years.

The yield losses to an extent of 18-32 percent have been recorded in susceptible soybean lines grown in Mississippi during years when rainfall was above normal in August and September. Jagtap et al., (2012) studied the eight of Marathwada region during June to August in Kharif, 2009 to 2010. In all, 69 soybean fields were surveyed (roving survey) for recording the severity and incidence of soybean bligh. 


\section{Materials and Methods}

\section{Survey and surveillance}

An intensive disease survey of the target leaf spot disease of soybean during June to August in Kharif 2015 was undertaken in different soybean growing area at Bemetra, Saja, Mungeli, Kawarda, Lohara, Gandai, Chhuhikhadan, Khairagarh, Rajnandgaon of Chhattisgarh region. Soybean fields of Chhuhikhadan and Khairagarh in Rajnandgaon district, Lohara and Gandai in Kawarda district, Saja in Bemetra district were observed for recording the incidence and severity of myrothecium leaf spot disease.

For recording of disease severity and disease incidence random five or six $1 \times 1 \mathrm{~m}^{2}$ area were marked in each field. Percent disease incidence was recorded by percent infected plant and calculated by the formula as given below. Disease severity was recorded by using 0-9 scale according to Singh et al., (1982) and per cent disease index (PDI) was worked out.

Where,

0 - No lesions

$1-1 \%$ leaf area covered with lesion

$3-1.1-10 \%$ leaf area covered with lesion

$5-10.1-25 \%$ of the leaf area covered no defoliation, little damage

$7-25.1-50 \%$ leaf area covered, some leaf drop, death of a few plant damage conspicuous.

9 -More than 50\% leaf area covered, lesion very common on all plants, defoliation common, death of plant common, damage more than $50 \%$.
PDI was calculated using the formula of Wheeler (1969) as given here

\section{Percent Disease}

Index $(\mathrm{PDI}) \quad=$

Sum of individual rating

100

Number of leaves examined Maximum disease rating

Percent disease

Incidence $=$

Number of plant infected

$\times 100$

Total number of plant examined

\section{Results and Discussion}

Survey and surveillance of target leaf spot disease in soybean growing area of Chhattisgarh

Data presented in table 1 indicated that the disease was prevailing in all surveyed soybean growing area of Chhattisgarh in severe to trace conditions.

Out of fifty-seven fields Target leaf spot was in severe form in five fields, moderate in twenty fields and trace in twenty-three fields while nine fields were found free from the Target leaf spot Among the surveyed fields Target leaf spot was observed maximum in eight fields of Kawardha blocks, followed by seven, seven, six fields of Khairagarh, Chhuikhadan and Gandai blocks respectively (Fig. 1). The result also showed that the incidence of Target leaf spot was more in variety JS 335 in comparison to JS 95-60. The maximum percent disease incidence $(53 \%)$ was observed in Kawardha block and Khairagarh also, followed by Chhuhikadan (50\%), Gandai (47\%), Saja (42\%), Lohara (40\%), Rajnandgaon (33\%) and Mungeli $(30 \%)$. 
Table.1 Severity of Target leaf spot of soybean in different blocks of Chhattisgarh region

\begin{tabular}{|c|c|c|c|c|c|c|c|}
\hline \multirow[t]{2}{*}{$\mathbf{S} / \mathbf{N}$} & \multirow{2}{*}{$\begin{array}{l}\text { Name of } \\
\text { Blocks }\end{array}$} & \multirow{2}{*}{$\begin{array}{l}\begin{array}{l}\text { Number of field } \\
\text { surveyed }\end{array} \\
\end{array}$} & \multirow[t]{2}{*}{ Variety } & \multicolumn{4}{|c|}{ Disease severity } \\
\hline & & & & Severe & Moderate & Trace & Free \\
\hline \multirow[t]{2}{*}{$\overline{1}$} & Rajnandgaon & 4 & JS 95-60 & - & 1 & - & - \\
\hline & & & JS-335 & - & 2 & 1 & - \\
\hline \multirow[t]{2}{*}{2} & Khairagarh & 7 & JS 95-60 & - & 1 & 1 & - \\
\hline & & & JS-335 & 1 & 2 & 2 & - \\
\hline \multirow[t]{2}{*}{3} & Chhuhikadan & 8 & JS 95-60 & - & 1 & 2 & 1 \\
\hline & & & JS-335 & 1 & 2 & 1 & - \\
\hline \multirow[t]{2}{*}{4} & Gandai & 7 & JS 95-60 & - & 1 & - & 1 \\
\hline & & & JS-335 & 1 & 2 & 2 & - \\
\hline \multirow[t]{2}{*}{5} & Lohara & 5 & JS 95-60 & - & 1 & 1 & - \\
\hline & & & JS-335 & - & 2 & 1 & - \\
\hline \multirow[t]{2}{*}{6} & Kawardha & 9 & JS 95-60 & - & 1 & 1 & 1 \\
\hline & & & JS-335 & 2 & 1 & 3 & - \\
\hline \multirow[t]{2}{*}{7} & Mungeli & 5 & JS 95-60 & - & - & 1 & 1 \\
\hline & & & JS-335 & - & 2 & 1 & - \\
\hline \multirow[t]{2}{*}{8} & Saja & 7 & JS 95-60 & - & 1 & 1 & 2 \\
\hline & & & JS-335 & - & 2 & 1 & - \\
\hline \multirow[t]{3}{*}{9} & Bemetra & 5 & JS 95-60 & - & - & - & 2 \\
\hline & & & JS-335 & - & 1 & 1 & 1 \\
\hline & GT & 57 & & 5 & 23 & 20 & 9 \\
\hline
\end{tabular}

Severe: > 50\%; Moderate: $>10 \%$ to $<50 \%$; Trace: $<10 \%$.

Table.2 Percent disease incidence target leaf spot of soybean in different blocks of Chhattisgarh region

\begin{tabular}{rccc}
\hline S. No. & Blocks & $\begin{array}{c}\text { Number of field } \\
\text { surveyed }\end{array}$ & $\begin{array}{c}\text { Disease incidence (\%) } \\
\text { (Average) }\end{array}$ \\
\hline $\mathbf{1}$ & Rajnandgaon & 5 & 33 \\
$\mathbf{2}$ & Khairagarh & 7 & 53 \\
$\mathbf{3}$ & Chhuhikadan & 8 & 50 \\
$\mathbf{4}$ & Gandai & 7 & 47 \\
$\mathbf{5}$ & Lohara & 9 & 40 \\
$\mathbf{6}$ & Kawarda & 5 & 53 \\
$\mathbf{7}$ & Mungeli & 5 & 30 \\
$\mathbf{8}$ & Saja & 7 & 42 \\
$\mathbf{9}$ & Bemetra & 5 & 28 \\
\hline Total & $\mathbf{5 7}$ & Average & $\mathbf{4 1 . 7 7}$ \\
\hline
\end{tabular}


Fig.1 Field infected with target leaf spot of soybean disease in different blocks of Chhattisgarh region

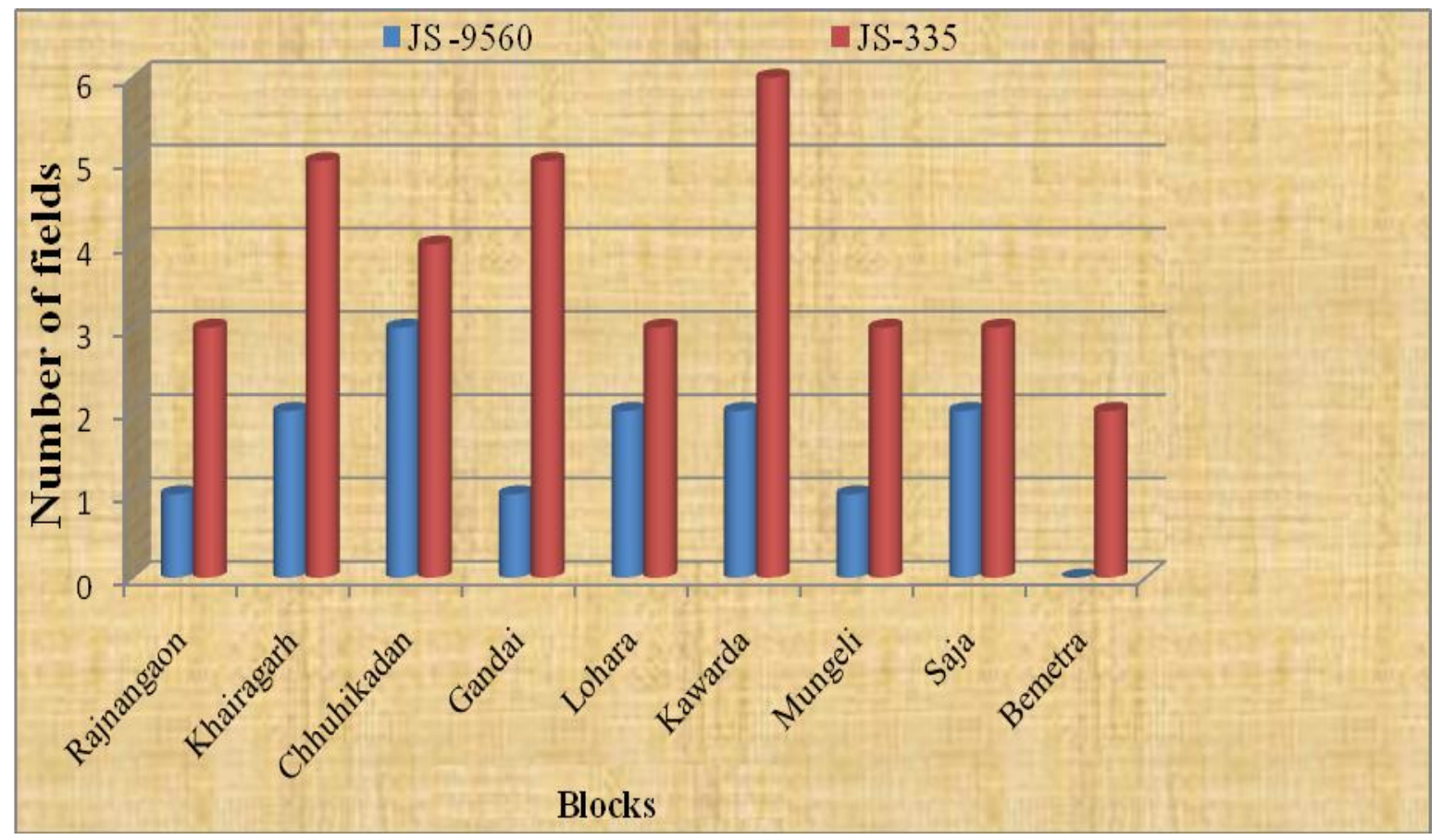

Fig.2 Percent disease incidence of target leaf spot of soybean in different blocks of Chhattisgarh region

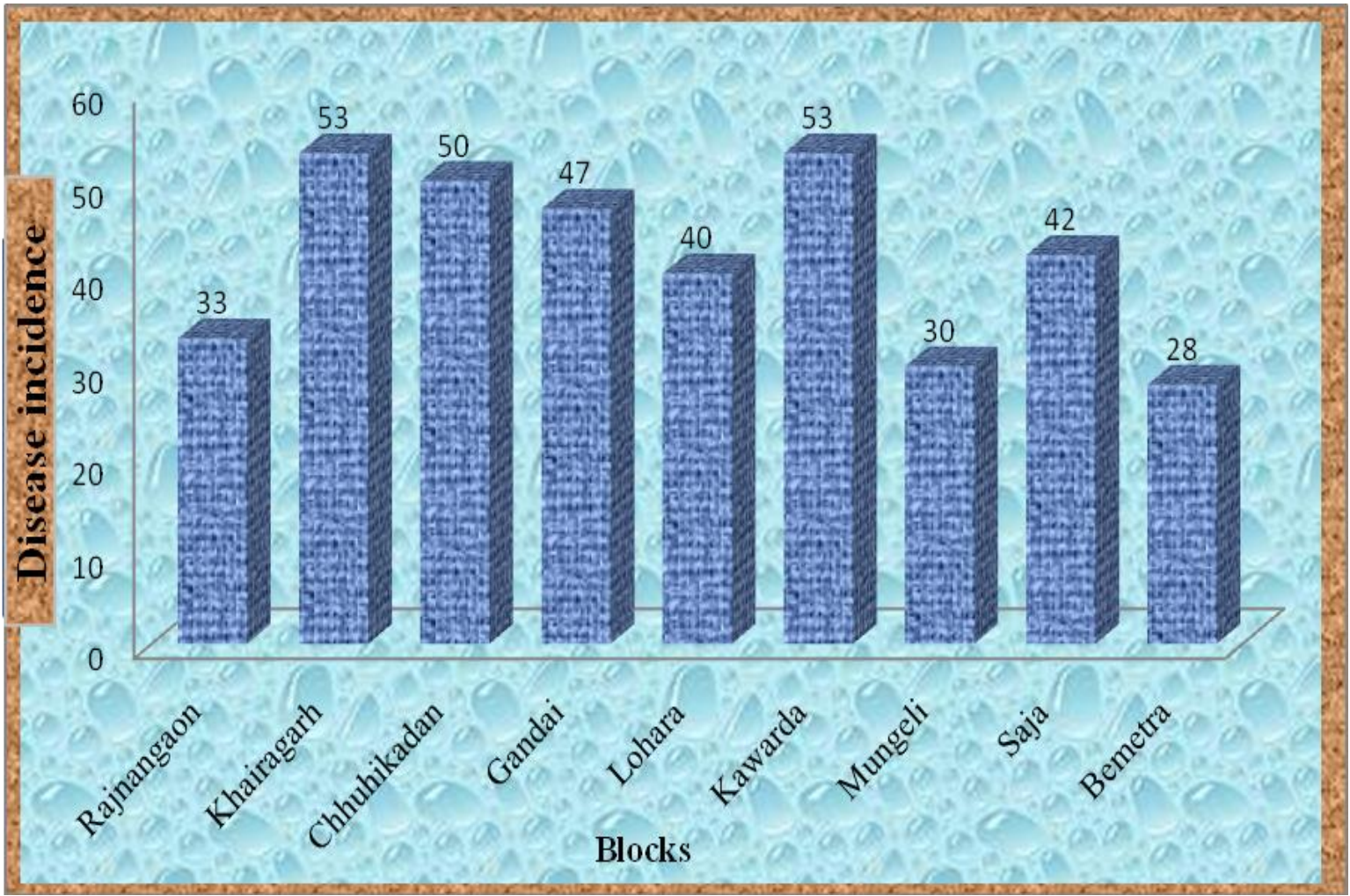


The minimum percent disease incidence (28\%) of target leaf spot of soybean was found in Bemetra block (Table 2 and Figure 2). Jagtap et al., (2012), surveyed in all, 69 soybean fields of eight districts (Parbhani, Nanded, Hingoli, Beed, Osmanabad, Jalna, Latur and Aurangabad) of Marathwada region were surveyed (roving survey) for recording the severity and incidence of soybean blight during June to August in Kharif, 2009 to 2010 .

\section{References}

Jagtap, G.P., Dhopte, S.B. and Dey, U. 2012. Survey, surveillance and cultural characteristics of bacterial blight of soybean. African Journal of Agricultural Research, 7(32): 45594563.

Patel, M.P. 2005. Studies on Corynesporacassiicola (Bark. and Curt.) Wei. Causing Target Spot of Soybean (Glycine Max (L.) Merrill)" M.Sc. (Ag.) Thesis, Indira Gandhi Agricultural University Raipur, p. 3.

Olive LS, Bain DC and Lefebvre C.L. 1945.A leaf spot of cowpea and soybean caused by an undescribed species of Helminthosporium. Phytopathology, 35: 822-831.

Sinclair, J.B. 1982. Compendium of soybean diseases. American Phytopathol. Society, 4: 27-28.

\section{How to cite this article:}

Arvind Kumar Kurre, Meghchand Dewangan and Kamalnarayan Koshle. 2017. Survey and Surveillance of Target Leaf Spot Disease (Corynespora cassiicola) in Soybean Growing Area of Chhattisgarh, India. Int.J.Curr.Microbiol.App.Sci. 6(8): 1598-1602. doi: https://doi.org/10.20546/ijcmas.2017.608.191 